\title{
Assessment of dietary habits and lifestyle among people with HIV
}

\author{
Paweł Duda ${ }^{1, A-F}$, Brygida Knysz ${ }^{2, B, D, E}$, Jacek Gąsiorowski2, ${ }^{2, B}$, Bartosz Szetela ${ }^{2, A-C}$, Ewa Piotrowska ${ }^{1, B, C, E}$, Monika Bronkowska ${ }^{1, A-F}$ \\ ${ }^{1}$ Department of Human Nutrition, Wroclaw University of Environmental and Life Sciences, Poland \\ 2 Department of Infectious Diseases, Liver Diseases and Acquired Immune Deficiencies, Wroclaw Medical University, Poland \\ A - research concept and design; $B$ - collection and/or assembly of data; $C$ - data analysis and interpretation; \\ $D$ - writing the article; $E$ - critical revision of the article; $F$ - final approval of the article
}

Address for correspondence

Monika Bronowska

E-mail: monika.bronkowska@upwr.edu.pl

Funding sources

None declared

\section{Conflict of interest}

None declared

Received on September 1,2020

Reviewed on September 19, 2020

Accepted on 0ctober 8, 2020

\begin{abstract}
Background. The aim of this study was to determine the consumption of specific food groups by people with HIV and to determine the quality of their diets.

Objectives. To assess the relationship between selected eating habits and lifestyles of people infected with HIV. The research was conducted at the HIV/AIDS Preventative and Therapeutic Clinic of the Infectious Disease Prevention and Therapy Center at Wrocław Health Center (SPZOZ Wrocław), Poland.
\end{abstract}

Material and methods. The study was conducted in 2019 among 31 patients of a counselling center in Wrockaw. To determine the frequency of food consumption and eating habits, the KomPAN ${ }^{\circledR}$ questionnaire, prepared by employees of the Polish Academy of Sciences, was used.

Results. All study participants were characterized by a small degree of unhealthy features in their diets; $87 \%$ of the respondents also demonstrated a small degree of healthy features in their diets, atthough the responses they gave showed that they assessed their nutritional knowledge and diet highly. Consumption of sweet snacks and adding salt to cooked meals were prevalent. The respondents took part in moderate physical activity and rarely consumed highly processed fast food products, though they ate fish and legumes - an important part of the diet - with similar frequency.

Conclusions. More attention should be given to the nutritional issues of patients treated for HIV, and emphasis should be placed on promoting healthy eating habits among this population. In the scientific literature, few such studies are available that address issues related to the diet of HIV-infected people.

Key words: lifestyle, quality index, eating behavior, nutrition in HIV, KomPAN

\section{Cite as}

Duda P, Knysz B, Gąsiorowski J, Szetela B, Piotrowska E, Bronkowska M. Assessment of dietary habits and lifestyle among people with HIV. Adv Clin Exp Med. 2020;29(12):1459-1467. doi:10.17219/acem/128234

DOI

10.17219/acem/128234

\section{Copyright}

Copyright by Author(s)

This is an article distributed under the terms of the

Creative Commons Attribution 3.0 Unported (CC BY 3.0)

(https://creativecommons.org/licenses/by/3.0/) 


\section{Introduction}

Researchers eagerly use nutritional questionnaires to assess subjects' eating habits, due to the low cost and simplicity. ${ }^{1}$ Their convenience is obvious, especially for the respondents: they can answer the questions at any time. Therefore, such questionnaires are a very useful tool for studying the lifestyles of populations who for various reasons try to minimize contact with others, as in the case of patients with human immunodeficiency virus (HIV). It is a retrovirus and a type of lentivirus (Lentiviridae) which causes long-term infections, leading to chronic diseases and, consequently, to death. ${ }^{2}$

Until now, it has not been possible to find a drug that would definitively terminate the development of this infection in the human body; however, the antiretroviral treatment (ARV) significantly reduces the multiplication of the virus, halting the weakening of the immune system and - in the case of people who follow ARV treatment - slowly rebuilding its functioning. At the very beginning, HIV infection presents with very uncharacteristic symptoms, so it is very rarely diagnosed during primary HIV infection. Only after the "window period" has passed, i.e., the period from infection to the formation of antiHIV antibodies in the blood - which usually lasts about 3 months - can the infection be diagnosed. If started early enough, ARV therapy prevents the occurrence of AIDS, so that the infected person can enjoy a long life (as long as an uninfected person), if only the daily medication intake regime is strictly followed. ${ }^{3}$

The HIV infection does not require a complete change in eating habits. However, paying attention to rational nutrition and the supply of essential nutrients is important. Meals should be varied and provide sufficient energy. The main aim of nutritional therapy should be to determine the amounts and variety of the foods consumed, which, apart from satisfying nutritional needs, should provide an adequate supply of the vitamins and minerals that benefit patient's health. ${ }^{11}$ It has been confirmed that the recommendation of a higher intake of certain nutrients is justified, because it reduces the risk of full-blown AIDS. Such ingredients include vitamins A, B6, B12, C, and E, magnesium, iron, selenium, and zinc. ${ }^{4}$

Currently in Poland, the care of a patient with HIV is mainly focused on pharmacotherapy, marginalizing the issues related to proper nutrition. ${ }^{5,6}$ However, several studies have confirmed that nutrition impacts the absorption and metabolism of drugs; therefore, the nutrition issue should receive more interest. ${ }^{6}$ In Poland, only few studies and some time ago have been carried out on the diets of people with HIV., ${ }^{7,8}$ More recent research frequently focuses on only one issue, without assessing the intake of various food groups. ${ }^{9}$ There are recommendations for increasing the consumption of some product groups and limiting the consumption of others. However, due to the lack of control over patients' diets, it cannot be clearly stated whether those with HIV are aware of the nutritional recommendations made for them. ${ }^{4,10}$ The aim of the study was to conduct a survey among seropositive people aged 1665 years using a questionnaire (KomPAN v. 1.2 $2^{11}$ ) to study their nutritional views and habits. The results of this study would determine the consumption of specific food groups and assess diet quality using diet quality indicators, according to the data development procedure, ${ }^{12}$ and also help determine whether patients present proper eating habits and which most common mistakes they make in terms of consuming specific food groups.

\section{Material and methods}

\section{Material}

The study involved 31 patients of the HIV/AIDS Preventative and Therapeutic Clinic of the Infectious Disease Prevention and Therapy Center at Wrocław Health Center (SPZOZ Wrocław) in Poland. The consent to conduct the research was issued by the Bioethics Committee at the Wroclaw Medical University (approval No. KB-326/2019). The study group consisted of men $(n=31)$ who had been infected with HIV through sexual contact with other men. Recruitment was performed at the Outpatient Clinic during patients' conversations with the doctors working there. During their periodic visits, the patients were informed about the purpose and scope of the tests, the voluntary nature of their participation and the possibility of resigning from the research at any time. In order to ensure anonymity, each study participant received their own code consisting of the letters "GB" and numbers ranging from 1 to 250 . The research was conducted in March-May 2019. The participants were asked to fill out the nutritional questionnaire and return it in pre-addressed envelopes.

\section{The KomPAN questionnaire}

The questionnaire used to assess patients' views and eating habits had 2 versions - one was used by the interviewer for questioning and the other was adapted for the participant to complete on his own. The questionnaire consisted of 4 parts:

- Part A, with questions about eating habits;

- Part B, with questions about the frequency in which individual food groups were consumed;

- Part C, regarding the participant's views on food and nutrition; and

- Part D, with questions about lifestyle and patient data. ${ }^{12}$

The participants were asked to complete the KomPAN questionnaire given to them, stating that they did not have to fill in Part C, since the scope of the research did not cover the respondents' views on food.

Based on the responses, it was possible to develop 2 dietary quality indicators: the healthy diet-10 index (pHDI-10) and the unhealthy diet-14 index (nHDI-14). The healthy 
Table 1. Combining the 2 questions regarding physical activity ${ }^{12}$

\begin{tabular}{|c|c|c|c|}
\hline \multirow[b]{2}{*}{ Physical activity at work/school } & \multicolumn{3}{|c|}{ Physical activity in free time } \\
\hline & $\begin{array}{c}\text { low } \\
\text { (predominantly sitting, watching } \\
\text { TV, reading newspapers } \\
\text { or books, light housework, } \\
\text { or walking; } 1-2 \text { h a week) }\end{array}$ & $\begin{array}{c}\text { moderate } \\
\text { (walking, cycling, } \\
\text { gymnastics, or other } \\
\text { light physical activity; } \\
\text { 2-3 h a week) }\end{array}$ & $\begin{array}{l}\text { high } \\
\text { (cycling, jogging, and other recreational } \\
\text { sports activities requiring physical } \\
\text { effort; over } 3 \mathrm{~h} \text { a week) }\end{array}$ \\
\hline $\begin{array}{l}\text { Low } \\
\text { (more than } 70 \% \text { of the time sitting) }\end{array}$ & low & low & moderate \\
\hline $\begin{array}{l}\text { Moderate } \\
\text { (about } 50 \% \text { of the time sitting and about } \\
50 \% \text { of the time moving) }\end{array}$ & low & moderate & moderate \\
\hline $\begin{array}{l}\text { High } \\
\text { (about } 70 \% \text { of the time moving or doing } \\
\text { physical work requiring heavy effort) }\end{array}$ & moderate & moderate & high \\
\hline
\end{tabular}

diet index included questions regarding the consumption of the following food groups: whole-meal bread, buckwheat, oatmeal, whole-grain pasta, or other coarse cereals, milk (including flavored milk, cocoa, and coffee with milk), fermented dairy drinks, cottage cheese (including homogenized cheese and cottage cheese desserts), poultry, fish, legumes, and fruit and vegetables. ${ }^{12}$

The nHDI-14 index was calculated based on the frequency in which the following product groups were consumed: light bread (e.g., wheat, rye, mixed wheat-rye, toasted bread, rolls, croissants, white rice, plain pasta, or small groats), fast food, meat- or flour-based fried foods, butter as an addition to bread or dishes for frying, baking, etc., lard as an addition to bread or dishes for frying, baking, etc., cheese (including processed cheese and blue cheese), cold cuts, processed sausages or frankfurters, red meat, sweets and other confectionery, canned meat, sweetened carbonated or noncarbonated drinks, energy drinks, and alcoholic beverages. ${ }^{12}$

Individual responses to the questionnaire were assigned the following values: $0-$ never, $0.06-1-3$ times a month, 0.14 - once a week, 0.5 - several times a week, 1 - once daily, and 2 - several times a day. The range of results for the pHDI-10 was $0-20$ points, while for the nHDI-14 it was $0-28$ points. In order to unify the 2 indices and facilitate comparisons (interpretation), it was decided to recalculate the total frequency of consumption and to express the result on a scale of $0-100$. A division into 3 categories of nutritional trait intensity was used: low (0-33), moderate (34-66) and high (67-100) intensity. ${ }^{12}$

The questionnaire also included questions about physical activity, both at work/school and in free time. Three answers could be given to these 2 questions: low, moderate or high activity. ${ }^{12}$ Table 1 presents the method of combining the 2 variants of physical activity.

\section{Statistical analysis}

The statistical analysis was performed using STATISTICA v. 13.1 software (StatSoft Inc., Tulsa, USA). The normality of the distribution was checked using the Shapiro-Wilk test.
The table also used cardinality tables and multi-tier tables. In order to check the interdependence of 2 variables, the $\chi^{2}$ test was used, assuming $\mathrm{p}<0.05$.

\section{Results}

\section{Participant characteristics}

The study was conducted among 31 patients, whose average age was 42 years. The youngest respondent was 26 years old, while the oldest was 65 years old. Most respondents lived in a city with at least 100,000 inhabitants. There were no participants with only a basic education. Almost half (48.3\%) of the respondents had a university degree. The same percentage of people described their financial situation as good. The largest group of respondents were diagnosed with HIV in the years 2016-2019 (35.5\%). However, the differences in the number of people between individual years were insignificant. ${ }^{34}$ Two patients did not specify the time when they learned about their infection. The characteristics of the study group are shown in Table 2.

\section{Eating habits and lifestyle}

Almost half (45.2\%) of the respondents ate 3 meals a day. A small percentage (9.7\%) reported consuming only 2 meals daily; others ate 4 or 5 . All ate between meals, usually several times a week (41.9\%), although there were those who snacked several times a day (29\%). Most willingly declared that they ate fruit and sweet snacks between meals $(87 \%$ and $64.5 \%$, respectively). Vegetables, sweetened beverages and dairy desserts were least preferred as snacks (both variants $22.6 \%)$. For spread, they usually used butter (32.3\%), although a large group did not use any fat when making sandwiches (22.6\%). For frying, most chose vegetable oil (51.6\%). The respondents generally did not sweeten hot drinks (41.9\%), though they added salt to cooked meals and sandwiches (58.1\%). Most ate out 1-3 times a month (51.6\%), although there were those who ate in bars, 
Table 2. Participant characteristics

\begin{tabular}{|c|c|c|}
\hline Variable & Number of people (n) & $\%$ \\
\hline \multicolumn{3}{|c|}{ Sex } \\
\hline Male & 31 & 100.0 \\
\hline \multicolumn{3}{|c|}{ Age [years] } \\
\hline $15-24$ & 0 & 0.0 \\
\hline $25-44$ & 17 & 54.8 \\
\hline $45-69$ & 14 & 45.2 \\
\hline \multicolumn{3}{|c|}{ Place of residence } \\
\hline Village & 8 & 25.8 \\
\hline Small town (<20,000 inhabitants) & 3 & 9.7 \\
\hline Town (20,000-100,000 inhabitants) & 9 & 29.0 \\
\hline City (>100,000 inhabitants) & 11 & 35.5 \\
\hline \multicolumn{3}{|c|}{ Financial situation of household } \\
\hline We live modestly or very modestly & 0 & 0.0 \\
\hline We live modestly & 3 & 9.7 \\
\hline We live normally & 10 & 32.3 \\
\hline We are relatively wealthy & 15 & 48.3 \\
\hline We are very wealthy & 3 & 9.7 \\
\hline \multicolumn{3}{|c|}{ Educational level } \\
\hline Primary & 0 & 0.0 \\
\hline Lower secondary & 4 & 12.9 \\
\hline Upper secondary & 12 & 38.8 \\
\hline Higher & 15 & 48.3 \\
\hline \multicolumn{3}{|c|}{ Time from detection of infection [years] } \\
\hline $0-3$ & 11 & 35.5 \\
\hline 4-9 & 9 & 29.0 \\
\hline$>10$ & 9 & 29.0 \\
\hline No data & 2 & 6.5 \\
\hline
\end{tabular}

restaurants or canteens once a day or more often $(13 \%$ in total). Twenty-two people were smokers, while 4 had quit smoking. Low physical activity at work or school was declared by $32.4 \%$; moderate activity was declared by $48.4 \%$, and high activity by $19.4 \%$. Taking into account physical activity in free time, the percentage of those who reported moderate physical activity decreased (41.9\%), while the number who assessed their activity as high was a few percentage points higher (22.6\%) (Table 5). Only 1 person rated their nutritional knowledge as very good; the majority of respondents described it as good (61.3\%). Others rated it as satisfactory $(25.8 \%)$ or insufficient $(9.7 \%)$. Seventy-one percent of people rated their diet as good, $25.8 \%$ as bad and $3.2 \%$ as very good (Table 6).

In analyzing the results concerning the influence of age, time since the initiation of treatment and time since diagnosis on the self-assessment of the patients' nutritional knowledge, a relationship was found between the time since diagnosis and the assessment of nutritional knowledge $(\mathrm{p}=0.03)$.

When comparing the assessment of diets among the patients, no significant relationships were observed between age, time since the infection was detected and time since the start of treatment.

Light bread was chosen more often as the bread consumed daily or more than once a week in comparison to whole-meal bread (Table 3). A similar tendency was observed in the case of white rice, plain pasta, and small groats: $38.7 \%$ of respondents ate these products more than once a week, while whole-grain products and coarse cereals were eaten only by $1 / 4$ of respondents. Most frequently they consumed the latter group of products 1-3 times a month (42\%). Over $1 / 10$ of the participants (12.9\%) never consumed whole grains or whole-meal bread (19.4\%). Fast food was not popular among the respondents - no one reported consuming this type of food more than once a week, and more than half (51.6\%) had it just 1-3 times a month. As many as $35.5 \%$ did not eat such food at all. A similar frequency of consumption as that of burgers, pizzas, fries, casseroles, and hot dogs was observed for fish - here as well 51.6\% most frequently ate fish 1-3 times a month, while $6.5 \%$ did not eat it at all and $16.1 \%$ did so more than once a week.

Fruit and vegetable consumption several times a day was reported by $22.6 \%$ and $19.4 \%$ of respondents, respectively. As many as $54.8 \%$ consumed fruit once a week, and $38.7 \%$ ate vegetables that often. With the same frequency as fruit (once a day), 22.6\% reached for sweets. However, most declared that they ate food from this group more than once a week. Cheese and cottage cheese were consumed once a week by $38.7 \%$ and $41.9 \%$, respectively, but the participants were more likely to choose yellow cheese on a daily basis. Eggs were most often consumed once a week or several times a week (48.4\% and 32.3\%), appearing on the menu every day for one respondent. Potatoes

Table 3. Anthropometric parameters of the study group

\begin{tabular}{|c|c|c|c|c|c|}
\hline Factor & Min & $\operatorname{Max}$ & M & $\pm \mathrm{SD}$ & Me \\
\hline Body height & 1.7 & 1.93 & 1.77 & 0.05 & - \\
\hline Body weight & 60 & 103 & 75.3 & 13.1 & - \\
\hline WHR & 0.86 & 1.06 & 0.96 & 0.05 & - \\
\hline Hip circumference & 80.0 & 112.0 & - & - & 90.0 \\
\hline Waist circumference & 74.0 & 115.0 & - & - & 85.5 \\
\hline BMI & 19.6 & 33.3 & - & - & 22.4 \\
\hline
\end{tabular}

WHR - waist-to-hip ratio; BMI - body mass index; Min - minimum; Max - maximum; M - mean; SD - standard deviation; Me - median. 
Table 4. Frequency (\%) of selected food consumption among participants

\begin{tabular}{|c|c|c|c|c|c|c|}
\hline Food & Never & $\begin{array}{l}1-3 \text { times } \\
\text { a month }\end{array}$ & Once a week & $\begin{array}{l}\text { More than } \\
\text { once a week }\end{array}$ & Once a day & $\begin{array}{l}\text { More than } \\
\text { once a day }\end{array}$ \\
\hline White bread & 3.2 & 19.4 & 0 & 32.2 & 22.6 & 22.6 \\
\hline Wholemeal bread & 19.4 & 22.6 & 12.9 & 25.8 & 12.9 & 6.4 \\
\hline White rice, white pasta, or fine-ground groats & 0 & 29.0 & 32.3 & 38.7 & 0 & 0 \\
\hline $\begin{array}{l}\text { Buckwheat, oats, wholegrain pasta, or other coarse- } \\
\text { ground groats }\end{array}$ & 12.9 & 42.0 & 16.1 & 25.8 & 3.2 & 0 \\
\hline Fried foods & 12.9 & 35.5 & 19.4 & 29.0 & 3.2 & 0 \\
\hline Fast foods & 35.5 & 51.6 & 12.9 & 0 & 0 & 0 \\
\hline Fish & 6.5 & 51.6 & 25.8 & 16.1 & 0 & 0 \\
\hline Fruits & 0 & 3.2 & 9.7 & 54.8 & 12.9 & 19.4 \\
\hline Vegetables & 0 & 6.5 & 6.5 & 38.6 & 25.8 & 22.6 \\
\hline Sweets & 3.2 & 9.7 & 9.7 & 48.4 & 22.6 & 6.4 \\
\hline Cheese & 3.2 & 25.8 & 12.9 & 38.7 & 16.2 & 3.2 \\
\hline Eggs & 0 & 16.1 & 48.4 & 32.3 & 3.2 & 0 \\
\hline Potatoes (excluding chips and fries) & 3.2 & 25.8 & 19.4 & 41.9 & 9.7 & 0 \\
\hline Fruit juices, vegetable & 6.4 & 25.8 & 9.7 & 51.6 & 0 & 6.5 \\
\hline Juices, fruit and vegetable juices & 19.4 & 38.7 & 12.9 & 29.0 & 0 & 0 \\
\hline Poultry meat & 3.2 & 12.9 & 16.1 & 67.8 & 0 & 0 \\
\hline Milk & 25.8 & 22.6 & 6.4 & 22.6 & 6.5 & 16.1 \\
\hline Fermented milk beverages & 3.2 & 29.0 & 16.1 & 35.5 & 9.7 & 6.5 \\
\hline Fresh cheese curd products & 6.5 & 29.0 & 19.4 & 41.9 & 3.2 & 0 \\
\hline Cold meats, smoked sausages, and hot dogs & 6.5 & 3.2 & 6.5 & 64.4 & 9.7 & 9.7 \\
\hline Red meat & 12.9 & 35.5 & 19.4 & 29.0 & 3.2 & 0 \\
\hline Legume dishes & 9.7 & 58.0 & 25.8 & 6,5 & 0 & 0 \\
\hline Canned meat & 45.2 & 48.4 & 3.2 & 3.2 & 0 & 0 \\
\hline Sweetened hot beverages & 29.0 & 6.5 & 0 & 9.7 & 6.5 & 48.3 \\
\hline Sweetened beverages & 22.6 & 41.9 & 16.1 & 9.7 & 3.2 & 6.5 \\
\hline Energy drinks & 80.6 & 19.4 & 0 & 0 & 0 & 0 \\
\hline Water & 3.2 & 12.9 & 0 & 22.6 & 12.9 & 48.4 \\
\hline Alcoholic beverages & 29.0 & 38.6 & 16.1 & 16.1 & 0 & 0 \\
\hline
\end{tabular}

Table 5. Physical activity (\% of people)

\begin{tabular}{|l|c|c|c|}
\multicolumn{1}{|c|}{ Physical activity } & Low & Moderate \\
\hline At work or school & 32.3 & 48.4 \\
\hline During free time & 35.5 & 41.9 \\
\hline
\end{tabular}

Free-time physical activity did not depend on the time since detection of the infection $(p=0.38)$, but it did depend on the age of the respondents $(p=0.045)$. There was no significant effect of the above times on physical activity at work or at school.

Table 6. The respondents' assessment of their own nutritional knowledge and diet

\begin{tabular}{|l|c|c|c|c|}
\multicolumn{1}{|c|}{ Parameter } & Very good & Good & Bad \\
\hline Nutritional knowledge & 3.2 & 61.3 & 25.8 \\
\hline Diet & 3.2 & 71.0 & 9.7 \\
\hline
\end{tabular}

were also consumed more often than once a week, in a form other than chips or fries, although a large group (25.8\%) consumed them 1-3 times a month.

Vegetable and vegetable-fruit juices were not very popular among the study participants $-19.4 \%$ never consumed them compared to $6.4 \%$ who never consumed fruit juices. The latter were most often consumed once a week (51.6\%). Most often, the respondents had vegetable juices 1-3 times a month (38.7\%), while nobody drank this type of drink more than several times a week. 
As many as $67.8 \%$ ate poultry meat several times a week, nobody more often. Only one person gave up white meat completely. With similar frequency, the study participants declared consuming sausages, and frankfurters (64.5\%). In the case of red meat, $12.9 \%$ of respondents never consumed it, $35.5 \%$ did so $1-3$ times a month, and $29.0 \%$ several times a week. A total of $9.7 \%$ consumed it daily or several times a day, slightly less (6.5\%) once a week.

In the case of milk, cocoa or flavored milk, 25.8\% declared that they did not consume these products at all, $22.6 \% \mathrm{sev}-$ eral times a week and $16.1 \%$ several times a day. Fermented dairy drinks such as yogurt and kefir, both plain and flavored, were quite popular among the respondents. It was observed that $35.5 \%$ of people consumed them several times a week, $9.7 \%$ once a day and $6.5 \%$ several times a day.

Over half of the respondents (58.1\%) ate legumes and dishes containing them only $1-3$ times a month; $25.8 \%$ reported eating legumes once a week, while $9.7 \%$ did not eat them at all. Canned meats were not very popular - as many as $93.6 \%$ consumed them 1-3 times a month or never. Overall, $80.6 \%$ did not consume energy drinks and nobody consumed them more often than 1-3 times a month.

Water and sweetened hot drinks such as tea, coffee or fruit/herbal teas were the most common daily drinks: both types of drinks were consumed several times a week by almost half of the respondents (48.4\%). A significant number did not consume sweetened hot drinks at all (29\%). Sweetened carbonated drinks were not very popular among this group of people, since $41.9 \%$ consumed them 1-3 times a month and $22.6 \%$ not at all. Alcohol was consumed most often $1-3$ times a month by $38.7 \%$; whereas $29.0 \%$ did not drink it at all. People who consumed alcohol most often reported drinking beer (45.2\%).

\section{Diet quality indices}

Table 7 shows the values for the healthy and unhealthy diet indices. The average pHDI-10 result for the whole study group (21.1\%) means that they show a small degree of dietary health features. On the other hand, in the case of the average nHDI-14 result, the mean value of $15.5 \%$ places them in the category of a small degree of unhealthy features. Only 4 patients had a healthy diet index above 33 points, which means their diet can be described as having a moderate degree of healthy features. None of the participants had a diet with a large degree of prohealth features. In the case of nHDI-14, the diets of all participants were qualified as diets with a small degree of unhealthy traits, i.e., none of the participants scored more than 33 points.

Using the $X^{2}$ test, it can be observed that the time since diagnosis does not significantly affect the value of the healthy diet index $(p=0.06)$. However, the time since the start of treatment significantly affects the value of the pHDI-10 index ( $\mathrm{p}=0.02)$ (Table 8$)$.

In the breakdown into individual periods since the detection of the infection, the highest index of a healthy diet was observed in patients who were diagnosed 10 years ago or earlier, while the lowest pHDI-10 belonged to patients with HIV diagnoses 4-9 years ago. Patients with an infection detected more than 10 years ago or earlier are also characterized by the lowest index of an unhealthy diet; this means that their diet has the smallest degree of unhealthy dietary features among all the respondents. The highest nHDI-14 index was observed among people with recent diagnoses (Table 8).

\section{Discussion}

The topic of HIV infection is currently being discussed by scientists and doctors in Poland. Along with the development of medicine around the world, research is underway whose results are supposed to provide an improvement in the nutritional status of HIV-infected patients and positively affect the functioning of their immune systems. The role of nutritional intervention is also to prevent weight loss or excessive weight gain. ${ }^{13}$ The role of this study

Table 7. Dietary quality indices (\%)

\begin{tabular}{|l|l|l|l|l|l|l|}
\hline \multicolumn{1}{|c|}{ Diet index } & N & M & Min & Max & Q1 & Q3 \\
\hline pHDI-10 & 31 & 21.1 & 3.8 & 48.5 & 12.3 & 30.6 \\
\hline nHDl-14 & 31 & 15.5 & 3.1 & 27.7 & 10.9 & 20.9 \\
\hline
\end{tabular}

$\mathrm{N}$ - number; $\mathrm{M}$ - mean; Min - minimum; Max - maxiumum; Q1 - 1st quartile; Q3 - $3^{\text {rd }}$ quartile.

Table 8. The value of dietary quality indicators depending on the time of the infection detection

\begin{tabular}{|l|c|c|c|}
\hline \multicolumn{1}{|c|}{ Time since the infection was detected [years] } & N & pHDI-10 \\
\hline $0-3$ & 11 & 22.5 & 18.3 \\
\hline $4-9$ & 9 & 15.3 & 17.9 \\
\hline 10 & 9 & 23.4 & 12.9 \\
\hline No data & 2 & 25.3 & 5.9 \\
\hline
\end{tabular}


was to identify the dietary habits and frequency which with individual food groups are consumed, so that in the future - in cooperation between doctors, patients and dietitians - the best solutions can be worked out, resulting in the best care for the patient not only from the attending physician, but also from representatives of other disciplines. Knowing the frequency of food intake will also shed light on the current nutritional trends of patients and, if necessary, enable undertaking nutritional intervention.

According to the currently adopted recommendations for patients infected with HIV, it is recommended to eat 4-6 meals a day, which stems from the need for a steady supply of basic nutrients from the diet. ${ }^{5}$ Our analysis of the results shows that respondents usually eat 3 meals a day. In addition, frequent snacking between meals was observed. Snacking between meals may be caused by the low caloric value of the meals consumed or an uneven distribution throughout the day, which further confirms the belief that the recommendation of 4-6 meals a day in the diet of seropositive patients should be followed. A low number of meals is one of the basic mistakes related to nutrition, while it is worth noting here that over $61 \%$ of people described their nutritional knowledge as good or very good.

Usually, when snacking, subjects reach for fruit, but a large group of people also declared that they choose sweets. Almost half of the respondents consumed sweets several times a week, and almost $1 / 3$ do so daily or several times a day. Therefore, the risk of not only obesity, but also other diseases such as caries, type 2 diabetes and cardiovascular diseases is higher. ${ }^{14-17}$ Sugar consumption should be limited not only because of the abovementioned diseases, but also because ARV therapy alone causes weight gain in $30-50 \%$ of patients. ${ }^{5}$ A large group of people add salt to cooked meals. Without recording the exact amounts of salt they add to dishes, it cannot be clearly determined whether these people consume significant a mounts of salt, but taking into account the trends of Poles in the consumption of salt, ${ }^{18}$ the addition of salt to dishes should be limited.

In the area of cereal consumption, there are no clear guidelines in Poland regarding the quantity and type of such products for people with HIV, but considering that this type of food is on one of the basic levels of the Pyramid of Healthy Nutrition and Physical Activity, ${ }^{19}$ the selection of these products should be adapted to the recommendations of the Institute of Food and Nutrition, i.e., they should be mainly whole grains, containing more $B$ vitamins and fiber than white bread or plain pasta. ${ }^{20}$ It is worth mentioning that the intake of vitamins and minerals by HIV-infected patients is recommended to be $100-150 \%$ of the recommended daily intake for other adults. ${ }^{5,34}$ In view of these recommendations, unfavorable trends can be observed among the respondents in that they consume much more white bread and processed products, such as white rice and plain pasta, than products from so-called full milling.

One very positive aspect is the subjects' avoidance or very rare consumption of fast food. In view of the generally high proportion of fats in the diet and the risk of lipid disorders in people with $\mathrm{HIV},{ }^{21,22}$ it is a good sign that the respondents are limiting highly-processed fast foods. Considering the current recommendations in terms of fish consumption for healthy people, ${ }^{20,33}$ it is worth focusing on problem of how rarely of these products are consumed. Patients should be advised to increase their fish intake due to the documented benefits of reducing low-densitylipoprotein (LDL) cholesterol and improving the overall lipoprotein profile. ${ }^{22,32}$

The consumption of fruit and vegetables was very low for the respondents in comparison with the current recommendations. ${ }^{19,20,35}$ Only $1 / 5$ of participants consumed fruit and vegetables several times a day; most reported consuming them several times a week. This is significant because vitamins and minerals have been proven many times ${ }^{24,25,29}$ to have a positive influence on the defense mechanisms of the body. This study shows that fruit and vegetable juices were a substitute for fruit and vegetables in the daily diet of the respondents - both types were consumed several times a week, but not every day. The good news is that there was minimal consumption of energy drinks - only $1 / 5$ consumed them 1-3 times a month, the rest never. However, the high consumption of sweetened hot drinks may be worrying. Alcoholic beverages were consumed by a total of $71 \%$, of which over half did so $1-3$ times a month. Various studies and recommendations require that virtually all alcohol be eliminated from the diet of HIV-positive patients, due to possible adverse interactions with ARV drugs. ${ }^{4,5,28}$

In accordance with the principles of healthy eating, adults should consume at least 2 large glasses of milk every day or replace them with fermented milk beverages. Research shows that almost a quarter do not consume milk at all, while only slightly over $21 \%$ consume milk once or several times a day. Fermented milk drinks were consumed with the same frequency by about $15 \%$ of respondents. As many as $22.6 \%$ and $29 \%$ of subjects reported consuming milk and dairy drinks only 1-3 times a month, respectively. It has been proven that people with HIV have a higher risk of bone disease: for osteopenia, the risk ranges from $22 \%$ to even $77 \%$. Increased catabolism of vitamin D occurs with some drugs. $5,25,26,30$ Therefore, dairy products should feature in the daily diet as a good source of calcium, although some scientists note that fermented dairy beverages (and raw eggs) should be limited because of the possibility of bacterial growth and their negative impact on a weakened immune system. ${ }^{4,27,31}$

Proper nutrition helps improve not only health, but also the quality of life of HIV-positive people. It can eliminate the occurrence of significant malnutrition in infected people as well as a deficit of minerals and vitamins with immunostimulating properties (vitamins B, A, C, and E). Proper nutrition also reduces the undesirable effects of ARV therapy (hyperglycemia and hypercholesterolemia). ${ }^{5}$

Although patients rated their nutritional knowledge and diet highly, this did not translate into the dietary quality 
as calculated in the study. The fact that all participants displayed a small degree of unhealthy dietary features is encouraging, as it may indicate that they actually have nutritional knowledge about restricting certain products which are not recommended for their daily diet. However, the patients' own nutritional assessment does not transfer into their diet having strong features of a healthy diet. In this aspect, one should strive to make patients more aware about the importance of products included in the diet as components of a healthy dietary index.

\section{Conclusions}

Patients appraise their nutritional knowledge highly, although this does not always translate into the quality of their diet. People with a newly diagnosed infection do not pay as much attention to what they eat, which makes the average unhealthy diet index in this group much higher than in the other groups. Eating habits change with the passage of time after diagnosis, which translates into a decrease in nHDI-14 values and an increase in the proportion of products classified as having pro-health properties. Eating fruit and vegetables too rarely is also a noticeable problem, though it is satisfactory that HIV-positive people rarely eat highly processed foods.

\section{ORCID iDs}

Paweł Duda (10) https://orcid.org/0000-0002-7907-5974 Brygida Knysz (1) https://orcid.org/0000-0003-2605-1079 Jacek Gąsiorowski (1) https://orcid.org/0000-0001-5039-4579 Bartosz Szetela (1) https://orcid.org/0000-0001-7178-9801 Ewa Piotrowska (10) https://orcid.org/0000-0002-8899-2010 Monika Bronkowska [1] https://orcid.org/0000-0003-2960-6981

\section{References}

1. Cade HE, Burley, VJ, Warm DL, Thompson RL, Margetts BM. Foodfrequency questionnaires: A review of their design, validation and utilization. Nutr Res Rev. 2004;17(1):5-22.

2. Gładysz A, Knysz B. Zakażenia HIV i AIDS - poradnik dla lekarzy. Wrocław Poland: Wydawnictwo Continuo; 2014.

3. Horban A, Podlasin R, Cholewińska G, et al., eds. Zasady opieki nad osobami zakażonymi wirusem HIV. Zalecenia Polskiego Towarzystwa Naukowego AIDS 2018. Warszawa-Szczecin, Poland: Polskie Towarzystwo Naukowe AIDS; 2018.

4. Lebiedzińska A, Bierżycka N, Lemańska M, et al. Assessment of energy value of daily food rations of HIV-positive adults. Rocz Panstw Zakl Hig. 2009;2(60):191-194.

5. Tomaszewska-Olijarczyk A, Rozpłochowski B, Kierepa A, Mozer-Lisewska I, Kowala-Piaskowska A. Dietary management in people infected with HIV. In: Parczewski M, Bociąga-Jasik M, eds. Rules for the Care of People Infected with HIV: PTN AIDS Recommendations 2019. $2^{\text {nd }}$ ed. Warszawa, Poland: Polskie Towarzystwo Naukowe AIDS; 2019:356-363.

6. Stojanović D, Marković D, Kocić G. Nutrition and patients with HIV/ AIDS. Acta Medica Medianae. 2011;50(3):63-68. doi:10.5633/amm. 2011.0312

7. Maksymowicz-Jaroszuk J, Grzeszczuk A, Filon J, Karczewski J. Assessment of nutrition and nutritional status of patients infected with HIV from the Podlasie area. Probl Hig Epidemiol. 2013;94(4):919-922.

8. Lebiedzińska A, Bierżycka N, Lemańska $\mathrm{M}$, et al. Assessment of energy value of daily food rations of HIV-positive adults. Rocz Panstw Zakl Hig. 2009;2(60):191-199.
9. Labban L. The implications of HIV/AIDS on the nutritional status and the MNT for its patients. EC Nutrition. 2016;3(4):680-686.

10. Stradling C. HIV. In: Payne A, Barker H, eds. Dietetics and Clinical Nutrition. $2^{\text {nd }}$ ed. Wrocław, Poland: Urban \& Partner Medical Publishing; 2010:159-180.

11. Jezewska-Zychowicz M, Gawecki J, Wadolowska L, et al. Dietary habits and nutrition beliefs questionnaire for people 15-65 years old, version 1.2 - self-administered questionnaire. In: Gawecki J, ed. Dietary Habits and Nutrition Beliefs Questionnaire and the Manual for Developing of Nutritional Data. The Committee of Human Nutrition, Polish Academy of Sciences: Olsztyn, Poland; 2018:21-33.

12. Wadolowska L, Krusinska B. The manual for developing nutritional data from the KomPAN ${ }^{\circledR}$ questionnaire. In: Gawecki J, ed. Dietary Habits and Nutrition Beliefs Questionnaire and the Manual for Developing Nutritional Data. The Committee of Human Nutrition, Polish Academy of Sciences: Olsztyn, Poland; 2018:34-52.

13. Kourkouta L, Monios A, Mihalache A, Iliadis C, Ouzounakis P, Dimitriadou A. AIDS and nutrition in patients. Prog Health Sci. 2017;7(1): 182-186.

14. Delli Bovi AP, Di Michele L, Laino G, Vajro P. Obesity and obesity related diseases, sugar consumption and bad oral health: A fatal epidemic mixtures: the pediatric and odontologist point of view. Transl Med UniSa. 2017;16;11-16.

15. Te Morenga L, Mallard S, Mann J. Dietary sugars and body weight: Systemic review and meta-analyzes of randomized controlled trials and cohort studies. BMJ. 2012;346:e7492. doi:https://doi.org/10.1136/ bmj.e7492

16. Kapczuk P, Komorniak N, Rogulska K, Bosiacki M, Chlubek D. Highly processed foods and its impact on the health of children and adults. Biochem Adv. 2020;1(66):23-29. doi:https://doi.org/10.18388/pb. 2020_309

17. Kłosiewicz-Latoszek L, Cybulska B. Sugar and the risk of obesity, diabetes and cardiovascular disease [in Polish]. Probl Hig Epidemiol. 2011;92(2):181-186.

18. Narodowe Centrum Edukacji Żywieniowej Instytutu Żywności i Żywienia. https://ncez.pl/abc-zywienia-/fakty-i-mity/dietapolakow-a-zalecenia-----za-tlusto--za-slono--za-slodko-. Warszawa, Poland: NCEZ IŻŻ; 2020. Accessed on March 28, 2020.

19. Narodowe Centrum Edukacji Żywieniowej Instytutu Żywności i Żywienia. https://ncez.pl/abc-zywienia-/zasady-zdrowego-zywienia/piramida-zdrowego-zyENIA- and physical-activity-for-adults. Warszawa, Poland: NCEZ IŻŻ; 2020. Accessed on March 28, 2020

20. Narodowe Centrum Edukacji Żywieniowej Instytutu Żywności i Żywienia. https://ncez.pl/abc-zywienia-/zasady-zdrowego-zywienia/podstawowe-zasady-zdrowego-zywienia. Warszawa, Poland: NCEZ IŻŻ; 2020. Accessed on March 28, 2020.

21. Drelichowska J, Kwiatkowska W, Knysz B, et al. Lipodystrophy syndrome in HIV-infected patients: A cohort study in Lower Silesia, Poland. HIV AIDS Rev. 2017;16(1):40-49. doi:10.5114/hivar. 2017.65114

22. Jackiewicz A, Czarnecki M, Knysz B. Effect of diet on lipid profile in HIV-infected patients. HIV AIDS Rev. 2018;17(3):159-163.

23. Wytyczne ESC/EAS dotyczące leczenia zaburzeń lipidowych w 2016 roku. Grupa Robocza Europejskiego Towarzystwa Kardiologicznego (ESC) i Europejskiego Towarzystwa Miażdżycowego (EAS) do spraw leczenia zaburzeń lipidowych. Kardiol Pol. 2016;74(11): 1234-1318. doi:10.5603/KP.2016.0157.

24. Lebiedzińska A, Bierżycka N, Lemańska $M$, et al. Vitamins in the diet of HIV-positive people [in Polish]. Bromatology and Toxicological Chemistry. 2009;42(3):672-677.

25. Grygiel-Górniak B, Puszczewicz M. Vitamin D: A new view in medicine and rheumatology [in Polish]. Postepy Hig Med Dosw (Online). 2014;68:359-368.

26. Pezzotti $P$, Napoli $P$, Acciai S. Increasing survival time after AIDS in Italy: The role of new combination antiretroviral therapies. Tuscany AIDS Study Group. AIDS. 1999:13(2):249-255.

27. Hendricks M, Eley B, Bourne L. Nutrition and HIV/AIDS in infants and children in South Africa: Implications for food-based dietary guidelines. Matern Child Nutr. 2007;3(4):322-333.

28. Knox TA, Zafonte-Sanders M, Fields-Gardner C, Moen K, Johansen D, Paton N. Assessment of nutritional status, body composition, and human immunodeficiency virus associated morphologic changes. Clin Infect Dis. 2003;36(Suppl 2):63-66. 
29. Capili B, Anastasi JK. Body mass index and nutritional intake in patients with HIV and chronic diarrhea: A secondary analysis. J Am Acad Nurse Pract. 2008;20(9):463-470.

30. Baum MK, Shor-Posner G, Bonvehi P, et al. Influence of HIV infection on vitamin status and requirements. Ann NY Acad Sci. 1992;669:165-174.

31. Beach RS, Mantero-Atienza E, Shor-Posner G, et al. Specific nutrient abnormalities in asymptomatic HIV-1 infection. AIDS. 1992;6(7):701-708.

32. Kotler D. Antioxidant therapy and HIV infection. Am J Clin Nutr. 1998; 67:7-9.

33. Hughes S, Kelly P. Interactions of malnutrition and immune impairment, with specific reference to immunity against parasites. Parasite Immunol. 2006;18(11):577-588.
34. Pribram V, Childs K, Poulton M. A nutritional screening audit of new adult out-patients with HIV. J Hum Nutr Diet. 2008;21(4):373-406.

35. Topping CM, Humm DC, Fischer RB, Brayer KM. A community-based, interagency approach by dietitians to provide meals, medical nutrition therapy, and education to clients with HIV/AIDS. J Am Diet Assoc. 1995;95(6):683-686.

36. Crofford S, Cashman L, Bush R, Moreland, K. Nutrition knowledge of persons with HIV/AIDS who use a Food Assistance Program. J Am Diet Assoc. 1999;9(99 Suppl):A92.

37. World Health Organization. Global Summary of the HIV/AIDS Epidemic. https://www.who.int/news-room/fact-sheets/detail/hiv-aids. Geneva, Switzerland: WHO; 2018. 